\title{
Cardioprotection by exenatide: A novel mechanism via improving mitochondrial function involving the GLP-1 receptor/cAMP/PKA pathway
}

\author{
GUANGLEI CHANG ${ }^{1}$, JIAN LIU ${ }^{1}$, SHU QIN ${ }^{1}$, YOUQIN JIANG ${ }^{1}$, PENG ZHANG ${ }^{1}$, HUI YU ${ }^{1}$, KAI LU ${ }^{1}$, \\ NAN ZHANG ${ }^{1}$, LI CAO $^{1}$, YING WANG ${ }^{1}$, YONG LI $^{2}$ and DONGYING ZHANG ${ }^{1}$ \\ ${ }^{1}$ Department of Cardiology, The First Affiliated Hospital of Chongqing Medical University, Chongqing, Sichuan 400016, \\ P.R. China; ${ }^{2}$ Center for Perinatal Biology, Division of Pharmacology, Department of Basic Sciences, \\ Loma Linda University School of Medicine, Loma Linda, CA 92350, USA
}

Received October 11, 2016; Accepted November 24, 2017

DOI: $10.3892 / \mathrm{ijmm} .2017 .3318$

\begin{abstract}
Accumulating evidence suggests that glucagon-like peptide-1 (GLP-1) and its analogues exert cardioprotective effects via modulating cardiomyocyte metabolism. Mitochondria play a pivotal role in the regulation of cell metabolism. It was hypothesized that treatment with exenatide, a GLP-1 analogue, may exert cardioprotective effects by improving mitochondrial function in an in vitro model of hypoxia/reoxygenation (H/R). H9c2 cells were employed to establish an in vitro model of $\mathrm{H} / \mathrm{R}$. Exenatide was added to the cells for $30 \mathrm{~min}$ prior to exposure to hypoxia. The GLP-1 receptor antagonist exendin-(9-39), the cyclic adenosine monophosphate (cAMP) inhibitor Rp-cAMPS and the protein kinase A (PKA) inhibitor H-89 were added to the cells for $10 \mathrm{~min}$ prior to treatment with exenatide. The release of lactate dehydrogenase $(\mathrm{LDH})$ and creatine kinase-MB (CK-MB) and cardiomyocyte apoptosis were evaluated. The characteristics of mitochondrial morphology and functions, including ATP synthesis, membrane potential $(\Delta \Psi \mathrm{m})$, mitochondrial permeability transition pore (mPTP), mitochondrial ATPase activity and oxidative stress, were determined. The mitochondrial uncoupling protein-3 (UCP-3) and nuclear respiratory factor-1 (Nrf-1) were also investigated by western blot analysis. Exenatide pretreatment significantly decreased LDH and CK-MB release and cardiomyocyte apoptosis in $\mathrm{H} 9 \mathrm{c} 2$ cells subjected to H/R. More importantly, to the best of our knowledge, this is the first report of exenatide pretreatment decreasing mitochondrial abnormalities and reducing oxidative
\end{abstract}

Correspondence to: Dr Dongying Zhang, Department of Cardiology, The First Affiliated Hospital of Chongqing Medical University, 1 Yixueyuan Road, Yuzhong, Chongqing, Sichuan 400016, P.R. China

E-mail: zdy.chris@gmail.com

Key words: glucagon-like peptide-1 analogue, mitochondrial function, exenatide, hypoxia/reoxygenation stress, while enhancing ATP synthesis, mitochondrial ATPase activity and $\Delta \Psi \mathrm{m}$ in $\mathrm{H} 9 \mathrm{c} 2$ cells subjected to $\mathrm{H} / \mathrm{R}$. Exenatide pretreatment also decreased mitochondrial calcium overload and inhibited the opening of MPTP in H9c2 cells subjected to $H / R$. Furthermore, exenatide pretreatment upregulated UCP-3 and Nrf-1 expression in H9c2 cells subjected to H/R. However, the abovementioned observed effects of exenatide were all abolished when exenatide was co-administered with exendin-(9-39), Rp-cAMPS and/or H-89. Therefore, the GLP-1 analogue exenatide was found to exert cardioprotective effects in an in vitro model of $\mathrm{H} / \mathrm{R}$, and this cardioprotection may be attributed to the improvement of mitochondrial function. These effects are most likely associated with the activation of the GLP-1 receptor/cAMP/PKA signaling pathway.

\section{Introduction}

Myocardial ischemia-reperfusion injury is defined as the sudden reintroduction of molecular oxygen due to blood flow restoration in the ischemic area, and it may cause additional injury to the myocardium (1). This pathological process occurs inevitably in a wide range of patients, such as cardiac arrest survivors, acute myocardial infarction victims and cardiac surgery patients (2). Although the underlying mechanism has not been fully elucidated, accumulating evidence indicates that mitochondrial dysfunction plays a key role in myocardial ischemia-reperfusion injury (3-7). Impaired myocardial mitochondrial function leads to diminished cardiac substrate flexibility, decreased cardiac energy efficiency and diastolic dysfunction (8-10). However, there are few effective strategies for preventing the process of mitochondrial dysfunction in myocardial ischemia-reperfusion injury. Therefore, identifying potential therapeutic agents that improve mitochondrial function in myocardial ischemia-reperfusion has become a field of interest in research.

Glucagon-like peptide-1 (GLP-1), an endogenous incretin hormone, has been confirmed to exert potent insulinotropic, insulinomimetic and glucagonostatic effects; however, its clinical use is limited by its rapid degradation by dipeptidyl peptidase-4 (DPP-4) (11). Exenatide, a GLP-1 analogue that 
is not susceptible to cleavage by DPP-4, has been developed and is currently being used as novel antidiabetic drug (11). Exenatide shares 53\% homology with native GLP-1, but still binds to GLP-1 receptors on pancreatic $\beta$-cells to exert its insulin-releasing and glucose-lowering effects (12). GLP-1 receptors have been found in extrapancreatic tissues, particularly in the heart $(13,14)$, and numerous studies have reported that GLP-1 and its analogues exert cardioprotective effects in myocardial ischemia-reperfusion injury, as well as in other pathologies that are associated with myocardial remodeling and heart failure (15-19). Recent evidence demonstrated that such cytoprotection appears to rely on direct mitochondrial preservation by modulating oxidative phosphorylation and inhibiting oxidative stress $(20,21)$. However, there is little information on the role of mitochondrial function in this cardioprotection. In this sense, this commonality in the beneficial effects on cardiac homeostasis between mitochondrial adjustment and GLP-1-mediated cardioprotection raises the question whether mitochondrial function improvement is a component of GLP-1-mediated cytoprotection against myocardial ischemia-reperfusion injury.

To address this question, in the present study, hypoxia/reoxygenation (H/R)-treated $\mathrm{H} 9 \mathrm{c} 2$ cells, an established in vitro model resembling ischemia-reperfusion in vivo, were used to determine the role of mitochondrial function in GLP-1-mediated cardioprotection. To test this hypothesis, characteristics of mitochondrial morphology and function, including ATP synthesis, membrane potential $(\Delta \Psi \mathrm{m})$, mitochondrial permeability transition pore (mPTP) and activities of mitochondrial ATPases were investigated, as was mitochondrial oxidative stress at the cellular level. Furthermore, the underlying mechanism for GLP-1-mediated cardioprotection was examined by assessing the GLP-1 receptor/cyclic adenosine monophosphate (cAMP)/protein kinase A (PKA) signaling pathway.

\section{Materials and methods}

Cell culture and H/R treatment. H9c2 cells (rat cardiomyoblast cell line; Chinese Academy of Medical Sciences, Shanghai, China) were cultured in Dulbecco's modified Eagle's medium/Nutrient Mixture F-12 (DMEM/F12; Thermo Fisher Biochemical Products, Beijing, China) containing 10\% (v/v) fetal bovine serum (FBS; Invitrogen Life Technologies; Thermo Fisher Scientific, Carlsbad, CA, USA) and $100 \mu \mathrm{g} / \mathrm{ml}$ penicillin/streptomycin (Beyotime Institute of Biotechnology, Haimen, China).

The H/R model was established according to the methods previously described, with some modifications (22). In brief, after growing to $80 \%$ confluence, the cells were starved in serumfree DMEM/F12 for $12 \mathrm{~h}$ and were then subjected to hypoxia in a hypoxic incubator (Thermo Forma, Marietta, OH, USA), saturated with a gas mixture $\left(95 \% \mathrm{~N}_{2}\right.$ and $\left.5 \% \mathrm{CO}_{2}\right)$ at $37^{\circ} \mathrm{C}$. The percent oxygen in the hypoxic incubator was maintained at $1 \%$ to induce simulated ischemia. After hypoxia treatment, the cells were provided with fresh $10 \%$ FBS DMEM/F12 and rapidly transferred into a normoxic incubator for reoxygenation. The control group was cultured under normal incubating conditions for the corresponding times. Exenatide or the cAMP activator, forskolin $(1 \mu \mathrm{M})$, was added to the cells for $30 \mathrm{~min}$ prior to exposure to hypoxia. The GLP-1 receptor antagonist exendin-(9-39) $(0.1 \mu \mathrm{M})$, the cAMP inhibitor Rp-Camps $(200 \mu \mathrm{M})$ and the PKA inhibitor $\mathrm{H}-89(5 \mu \mathrm{M})$ were added to the cells for $10 \mathrm{~min}$ prior to treatment with exenatide.

Viability assay. The cell counting kit-8 (CCK-8; Beyotime Institute of Biotechnology) was employed to examine cell viability as previously described (23). Briefly, H9c2 cells $\left(1 \times 10^{4} / 100 \mu \mathrm{l}\right)$ were seeded in 96 -well plates for $72 \mathrm{~h}$. The cells were then pretreated with or without exenatide $(0,0.05,0.1$, $0.2,0.4$ and $0.6 \mu \mathrm{M}$ ) for $30 \mathrm{~min}$ prior to being subjected to $\mathrm{H} / \mathrm{R}$ $(4 / 2,6 / 3,12 / 4,14 / 5,16 / 6$ and 22/10 h). The cells were provided with fresh media $(100 \mu \mathrm{l})$ and CCK-8 solution $(10 \mu \mathrm{l})$ was added into each well. The plates were then incubated under normoxic conditions for $2 \mathrm{~h}$. The optical density values were measured at $450 \mathrm{~nm}$ using a microplate reader (Multiskan MK33; Thermolab Systems, Helsinki, Finland).

Transmission electron microscopy. After the indicated treatment, cells were harvested by $0.25 \%$ trypsinization and centrifugation at $400 \mathrm{x} \mathrm{g}$ for $5 \mathrm{~min}$. The cells were then fixed with $2.5 \%$ glutaraldehyde for $2 \mathrm{~h}$ at $4^{\circ} \mathrm{C}$ and post-fixed with $1 \%$ osmium tetroxide for $15 \mathrm{~min}$ at $4^{\circ} \mathrm{C}$. After dehydration with a graded series of aceton, the cells were washed by propylene oxide and embedded in Epon 812. Ultrathin sections were cut with an ultramicrotome, stained with sodium acetate and lead hydroxide, and examined using a transmission electron microscope (Hitachi-7500; Hitachi, Tokyo, Japan)

Flow cytometry. Annexin V/propidium iodide (PI) staining was used to determine cell apoptosis by flow cytometry (24). H9c2 cells $\left(2 \times 10^{4} / 100 \mu \mathrm{l}\right)$ were seeded in 6 -well plates for $72 \mathrm{~h}$. After treatment, the cells were harvested by trypsinization and centrifugation at $400 \mathrm{x}$ g for $5 \mathrm{~min}$, and re-suspended at a density of $1 \times 10^{6} / \mathrm{ml}$. The cells were incubated with $5 \mu \mathrm{l}$ Annexin V-fluorescein isothiocyanate (FITC) and PI (10 $\mu 1$, $20 \mu \mathrm{g} / \mathrm{ml}$ ) for $20 \mathrm{~min}$, and then analyzed using a flow cytometer (BD FACSVantage SE; Beckman Coulter, Brea, CA, USA). The data on fluorescence intensity were analyzed using the CellQuest ${ }^{\mathrm{TM}}$ software (Becton Dickinson and Company, Franklin Lakes, NJ, USA).

To quantitatively analyze the development of oxidative stress, the generation of reactive oxygen species (ROS) and reactive nitrogen species (RNS) was assessed using 2',7'-dichlorofluorescin diacetate (DCFH-DA) and dihydroethidium (DHE) (both from Beyotime Institute of Biotechnology) by flow cytometry, as described previously (24). After the indicated treatment, the cells were loaded with DCFH-DA $(10 \mu \mathrm{M})$ for $60 \mathrm{~min}$ at $37^{\circ} \mathrm{C}$ and $\operatorname{DHE}(5 \mu \mathrm{M})$ for $30 \mathrm{~min}$ at $37^{\circ} \mathrm{C}$, and then analyzed on a flow cytometer. DCFH-DA was excited at $488 \mathrm{~nm}$ and emitted at $525 \mathrm{~nm}$. DHE was excited at $543 \mathrm{~nm}$ and emitted at $560 \mathrm{~nm}$. The data on fluorescence intensity were analyzed using the CellQuest ${ }^{\mathrm{TM}}$ software.

Changes in mitochondrial calcium concentration $\left[\left(\mathrm{Ca}^{2+}\right)_{\mathrm{m}}\right]$ were assessed using a mitochondrial-permeating calcium fluorophore, Rhod-2AM (Santa Cruz Biotechnology Inc., Santa Cruz, CA, USA), by flow cytometry as described previously (24). After the indicated treatment, the cells were incubated with $2 \mu \mathrm{M}$ Rhod-2AM for $30 \mathrm{~min}$ at $37^{\circ} \mathrm{C}$ and were then analyzed on a flow cytometer. Rhod-2AM was excited 
at $543 \mathrm{~nm}$ and emitted at $560 \mathrm{~nm}$. The data on fluorescence intensity were analyzed using the CellQuest ${ }^{\mathrm{TM}}$ software.

The opening of mPTP was detected using the calcein-AM probe (Santa Cruz Biotechnology, Inc.) by flow cytometry, as described previously (25). The loading of calcein-AM enabled the localization of fluorescent calcein in mitochondria, and the calcein signal was reduced when the MPTP opened (26). After the indicated treatment, the cells were loaded with calcein-AM $(1 \mu \mathrm{M})$ for $30 \mathrm{~min}$ at $37^{\circ} \mathrm{C}$ and were then analyzed on a flow cytometer. Calcein-AM was excited at $488 \mathrm{~nm}$ and emitted at $525 \mathrm{~nm}$. The data on fluorescence intensity were analyzed using the CellQuest ${ }^{\mathrm{TM}}$ software.

$\Delta \Psi \mathrm{m}$ was measured using a fluorescent, lipophilic and cationic probe, JC-1 (Beyotime Institute of Biotechnology) by flow cytometry, as described previously (7). After the indicated treatment, the cells were loaded with JC-1 $(10 \mu \mathrm{g} / \mathrm{ml})$ for $20 \mathrm{~min}$ at $37^{\circ} \mathrm{C}$ and were then were analyzed on a flow cytometer under single excitation $(488 \mathrm{~nm})$ and dual emission (530 and $590 \mathrm{~nm}$ ). The data on fluorescence intensity were analyzed using the CellQuest ${ }^{\mathrm{TM}}$ software. The fluorescence ratio of red to green was quantitated.

Detection of intracellular ATP content. Cellular ATP content was measured using the ATP bioluminescent assay kit (Beyotime Institute of Biotechnology) according to the manufacturer's instructions. In brief, after the indicated treatment, the cells were lysed and centrifuged at 12,000 x g for $5 \mathrm{~min}$. The supernatants $(100 \mu \mathrm{l})$ were mixed with ATP detection working dilution $(100 \mu \mathrm{l})$ in a 96 -well plate. The luminance was measured using a microplate reader (Multiskan MK33; Thermolab Systems). The protein concentration of each group was determined using the enhanced bicinchoninic acid (BCA) protein assay kit (Beyotime Institute of Biotechnology). The total ATP content was expressed as $\mathrm{nmol} / \mathrm{mg}$ protein.

Mitochondrial isolation. Mitochondria were isolated from $\mathrm{H} 9 \mathrm{c} 2$ cells using the Cell Mitochondria Isolation kit (Beyotime Institute of Biotechnology) according to the manufacturer's instructions. Briefly, after the indicated treatment, the cells were collected and suspended in ice-cold isolation buffer for $15 \mathrm{~min}$. After the cells were homogenized, the homogenate was centrifuged at $600 \mathrm{x} \mathrm{g}$ for $10 \mathrm{~min}$ at $4^{\circ} \mathrm{C}$, and then the supernatant was centrifuged at $11,000 \mathrm{x} \mathrm{g}$ for $10 \mathrm{~min}$ at $4^{\circ} \mathrm{C}$. The mitochondria were harvested from the sediments.

Colorimetry. The activity of lactate dehydrogenase (LDH) in the culture medium, and the activities of mitochondrial $\mathrm{Na}^{+} / \mathrm{K}^{+}$-ATPase and $\mathrm{Ca}^{2+} / \mathrm{Mg}^{2+}$-ATPase were measured using commercially available kits (Jiancheng Bioengineering Institute, Nanjing, China) according to the manufacturer's instructions. In brief, after the indicated treatment, the cells were lysed and centrifuged at $1,600 \mathrm{x} \mathrm{g}$ for $10 \mathrm{~min}$ at $4^{\circ} \mathrm{C}$. The mitochondria were isolated as described above. The supernatants and the mitochondria were collected and reacted with the respective reagents included in the kits. Subsequently, the absorbance values at 340 and $660 \mathrm{~nm}$ were measured using a spectrophotometer (721D; Pudong Shanghai Physical Optical Instrument Factory, Shanghai, China). The protein concentration of each group was determined using the enhanced BCA protein assay kit (Beyotime Institute of Biotechnology).
The activity of LDH was expressed as U/l. The activities of $\mathrm{Na}^{+} / \mathrm{K}^{+}$-ATPase and $\mathrm{Ca}^{2+} / \mathrm{Mg}^{2+}$-ATPase were expressed as $\mu \mathrm{mol} \mathrm{Pi} / \mathrm{mg}$ protein/h.

Enzyme-linked immunosorbent assay (ELISA). The levels of creatine kinase-MB (CK-MB) in the culture medium and plasma were measured using the CK-MB ELISA assay (R\&D Systems, Minneapolis, MN, USA), according to the manufacturer's instructions. After the indicated treatment, the culture medium and plasma was collected and centrifuged at $1,600 \mathrm{x}$ g for $10 \mathrm{~min}$ at $4^{\circ} \mathrm{C}$. The supernatants were collected for the detection of CK-MB. The supernatants were then incubated with the reagents in the kits. Finally, the absorbance values were measured using a microplate reader (Multiskan MK33; Thermolab Systems) at $450 \mathrm{~nm}$. The CK-MB level was expressed as U/1.

Western blot assay. Protein samples were isolated from the $\mathrm{H} 9 \mathrm{c} 2$ cells by homogenization in cell lysis buffer (Beyotime Institute of Biotechnology). The lysates were kept on ice for $45 \mathrm{~min}$ and total proteins were isolated by centrifugation at $14,000 \mathrm{x} \mathrm{g}$ for $10 \mathrm{~min}$ at $4^{\circ} \mathrm{C}$. The protein concentration was measured using the enhanced BCA protein assay kit (Beyotime Institute of Biotechnology). Proteins were separated by sodium dodecyl sulfate-polyacrylamide gel electrophoresis and transferred onto PVDF membranes. The membranes were blocked in $5 \%$ non-fat milk and incubated with primary antibodies to uncoupling protein (UCP)-3 (1:1,000; rabbit, polyclonal; C19359), nuclear respiratory factor (Nrf)-1 (1:1,000; rabbit, polyclonal; C20962) (both from Anbo Biotechnology Co., Ltd., San Francisco, CA, USA), and glyceraldehyde 3-phosphate dehydrogenase (GAPDH) (1:1,000; Beyotime Institute of Biotechnology). The membranes were then incubated with horseradish peroxidase-goat anti-rabbit immunoglobulin $\mathrm{G}$ secondary antibody (cat. no. ZDR 5306; 1:1,000; Zhongshan Goldenbridge Biotechnology Corporation, Beijing, China). Signals were detected with the ECL system (Beyotime Institute of Biotechnology). Blots were scanned using Bio-Rad gel imaging system (Bio-Rad Laboratories, Hercules, CA, USA) and bands were quantified with Quantity One software.

Statistical analysis. The SPSS 17.0 software (SPSS, Inc., Chicago, $\mathrm{IL}, \mathrm{USA}$ ) was used for statistical analysis. Data are presented as mean \pm standard deviation. Grouped data were analyzed using a one-way analysis of variance followed by the Student-NewmanKeuls test. When the equal variance test failed, a Mann-Whitney rank-sum test was used. A P-value of $<0.05$ was considered to indicate statistically significant differences.

\section{Results}

The GLP-1 receptor is expressed in H9c2 cells. Although the GLP-1 receptor has been found in the hearts of mammals, no information is available regarding its expression in $\mathrm{H} 9 \mathrm{c} 2$ cells. Therefore, the expression of GLP-1 receptor was first tested in $\mathrm{H} 9 \mathrm{c} 2$ cells using confocal laser scanning microscopy and western blot analysis (Fig. 1), and the expression of the GLP-1 receptor in $\mathrm{H} 9 \mathrm{c} 2$ cells was confirmed.

Exenatide increases the viability of $H 9 \mathrm{c} 2$ cells subjected to $H / R$. After H9c2 cells were exposed to various durations of 


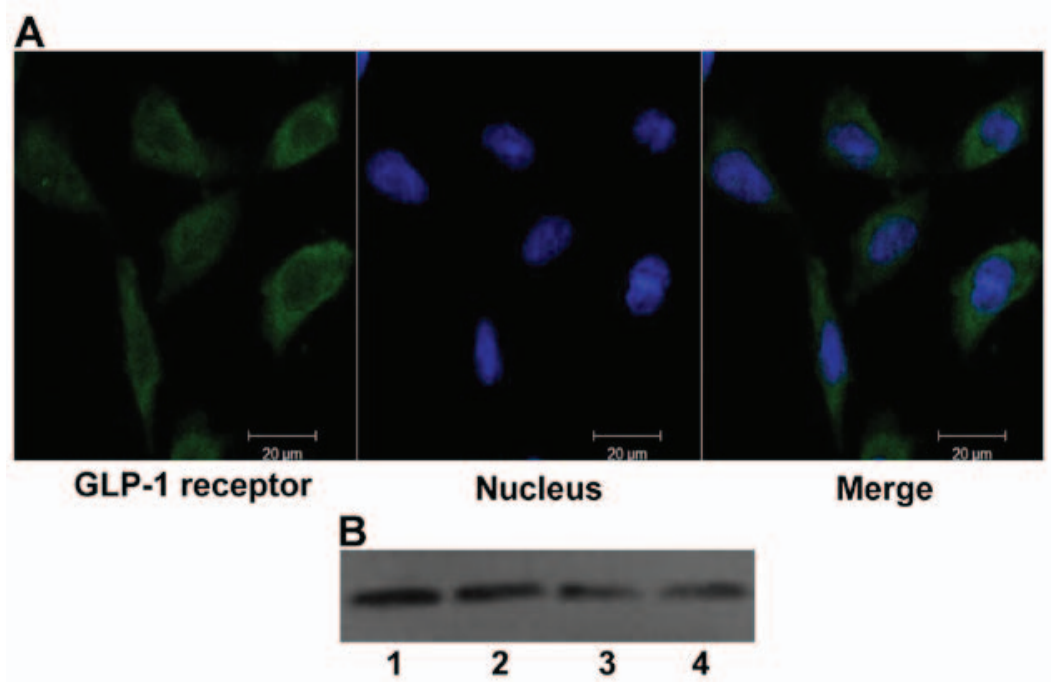

Figure 1. Glucagon-like peptide-1 (GLP-1) receptor is expressed in H9c2 cells. (A) GLP-1 receptor expression was measured by laser confocal microscopy. Green fluorescence, GLP-1 receptor; blue fluorescence, nuclei (magnification, x1,000), (B) GLP-1 receptor expression was measured by western blotting. Bands $1,2,3$ and 4 are from $\mathrm{H} 9 \mathrm{c} 2$ cells.

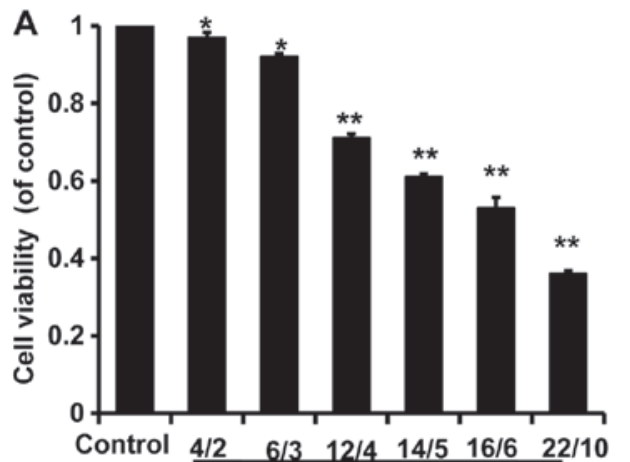

Hypoxia/Reoxygenation (h)

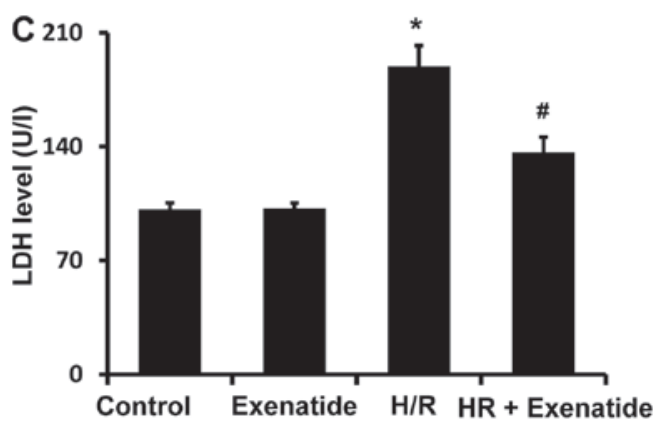

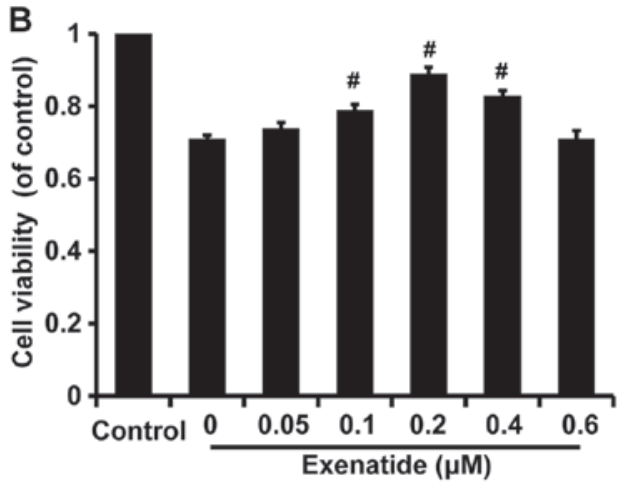

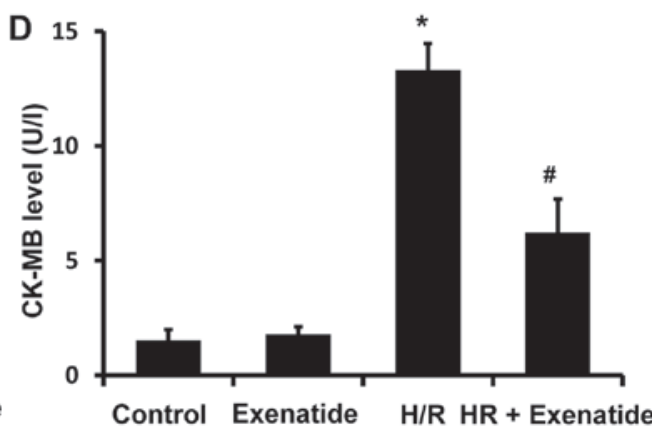

Figure 2. Effects of hypoxia/reoxygenation $(\mathrm{H} / \mathrm{R})$ on the viability of H9c2 cells and the protective effects of exenatide in H/R-injury. (A) H9c2 cells were exposed to $\mathrm{H} / \mathrm{R}$ conditions for different times $(4 / 2,6 / 3,12 / 4,14 / 5,16 / 6$ and 22/10 h). After treatment, cell viability was assessed using the cell counting kit-8 (CCK-8). Data are expressed as percentage of control and represented as mean $\pm \mathrm{SD} ; \mathrm{n}=6 .{ }^{*} \mathrm{P}<0.05 ;{ }^{* * *} \mathrm{P}<0.01$ vs. control group. (B) H9c2 cells were pretreated with exenatide $(0,0.05,0.1,0.2,0.4$ and $0.6 \mu \mathrm{M})$ for $30 \mathrm{~min}$ and underwent $12 \mathrm{~h}$ hypoxia followed by $4 \mathrm{~h}$ reoxygenation. After treatment, cell viability was assessed using the CCK-8 kit. Data are expressed as percentage of control and represented as mean $\pm \mathrm{SD} ; \mathrm{n}=6 .{ }^{*} \mathrm{P}<0.05$ vs. the 0 group. (C) Effects of exenatide on the lactate dehydrogenase (LDH) levels in the culture medium. $\mathrm{H} 9 \mathrm{c} 2$ cells were pretreated with exenatide $(0.2 \mu \mathrm{M})$ for 30 min and underwent $12 \mathrm{~h}$ hypoxia followed by $4 \mathrm{~h}$ reoxygenation. After treatment, the LDH levels in the culture medium were measured by colorimetry and expressed as U/l. (D) Effects of exenatide on the creatine kinase-MB (CK-MB) levels in the culture medium. H9c2 cells were pretreated with exenatide ( $0.2 \mu \mathrm{M})$ for 30 min and underwent $12 \mathrm{~h}$ hypoxia followed by $4 \mathrm{~h}$ reoxygenation. After treatment, the CK-MB levels in the culture medium were measured by ELISA and expressed as U/l. Values are expressed as means $\pm \mathrm{SD} ; \mathrm{n}=6 .{ }^{*} \mathrm{P}<0.05$ vs. control group; ${ }^{*} \mathrm{P}<0.05$ vs. $\mathrm{H} / \mathrm{R}$ group. $\mathrm{SD}$, standard deviation.

$\mathrm{H} / \mathrm{R}(4 / 2,6 / 3,12 / 4,14 / 5,16 / 6$ and $22 / 10 \mathrm{~h})$, cell viability was assessed with the CCK-8 kit and was found to be significantly decreased in a time-dependent manner compared with the control group (Fig. 2A). Cell viability after $4 / 2$ and $6 / 3 \mathrm{~h}$ $\mathrm{H} / \mathrm{R}$ was reduced to 0.96 and 0.92 (\% of control), respectively, compared with that in the control group $(\mathrm{P}<0.05)$, while cell viability was reduced to $0.71,0.61,0.53$ and 0.36 after $12 / 4$, $14 / 5,16 / 6$ and $22 / 10 \mathrm{~h} \mathrm{H} / \mathrm{R}$, respectively $(\mathrm{P}<0.01) . \mathrm{H} / \mathrm{R} 12 / 4 \mathrm{~h}$ was selected to investigate the potential protective effects of exenatide on cardiomyocytes, as it was the earliest time-point 


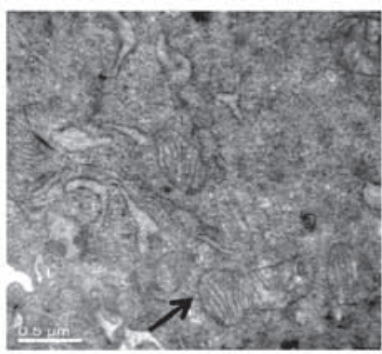

Control

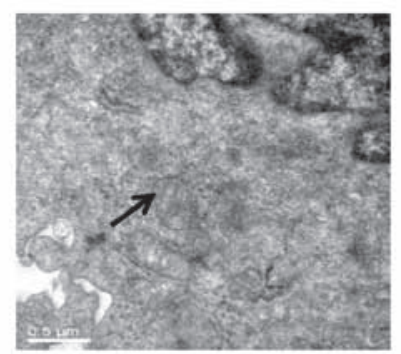

Exenatide

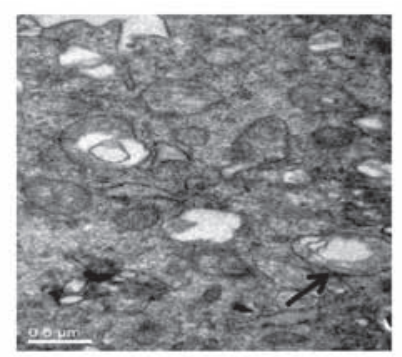

H/R

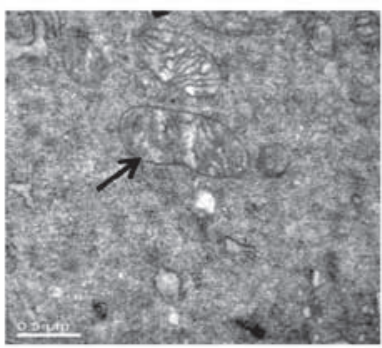

HR + Exenatide

Figure 3. Effects of exenatide on mitochondrial morphology in H9c2 cells. H9c2 cells were pretreated with exenatide (0.2 $\mu \mathrm{M})$ for 30 min and underwent $12 \mathrm{~h}$ hypoxia and then $4 \mathrm{~h}$ reoxygenation. After treatment, mitochondrial morphology (arrows) was evaluated by transmission electron microscopy (magnification, $\mathrm{x} 30,000)$.

when cell viability exhibited a statistically significant difference $(\mathrm{P}<0.01)$.

To investigate the possible cardioprotective effects of exenatide against $\mathrm{H} / \mathrm{R}$ injury, $\mathrm{H} 9 \mathrm{c} 2$ cells were pretreated with exenatide $(0,0.05,0.1,0.2,0.4$ and $0.6 \mu \mathrm{M})$ for $30 \mathrm{~min}$ prior to undergoing $12 / 4 \mathrm{~h} \mathrm{H} / \mathrm{R}$. It was observed that pretreatment with exenatide $(0.1,0.2$ and $0.4 \mu \mathrm{M})$ successfully alleviated the decrease of cell viability induced by $\mathrm{H} / \mathrm{R}$ injury $(\mathrm{P}<0.05)$ (Fig. 2B). Exenatide at $0.2 \mu \mathrm{M}$ exhibited the best efficiency in preserving cell viability. Thus, the concentration of $0.2 \mu \mathrm{M}$ was selected to treat $\mathrm{H} 9 \mathrm{c} 2$ cells in the following experiment.

LDH and CK-MB release are two well-known markers of cardiomyocyte injury. To further investigate the cardioprotection of exenatide against H/R injury, $\mathrm{LDH}$ and CK-MB release in the culture medium was further examined (Fig. 2C and D). $\mathrm{LDH}$ and $\mathrm{CK}-\mathrm{MB}$ release was significantly increased in the $\mathrm{H} / \mathrm{R}$ group compared with the control group $(\mathrm{P}<0.05)$, while pretreatment with $0.2 \mu \mathrm{M}$ exenatide significantly decreased $\mathrm{LDH}$ and $\mathrm{CK}-\mathrm{MB}$ release induced by $\mathrm{H} / \mathrm{R}(\mathrm{P}<0.05)$. These results strongly suggest that exenatide exerted cardioprotective effects against $\mathrm{H} / \mathrm{R}$ injury in $\mathrm{H} 9 \mathrm{c} 2$ cells.

Exenatide inhibits structural changes in mitochondria. Transmission electron microscopy was used to detect mitochondrial structural changes. As shown in Fig. 3, mitochondria in the control cells presented as integrated structures with numerous transversely orientated cristae enveloped by an intact outer membrane. However, H/R injury resulted in swollen mitochondria, appearing as spherical structures with disarrayed cristae, disorganized matrix and more cytosolic vacuoles. Exenatide treatment attenuated mitochondrial swelling, cristae disarray and membrane rupture in $\mathrm{H} 9 \mathrm{c} 2$ cells following H/R.

Exenatide protects $\mathrm{H} 9 \mathrm{c} 2$ cells from apoptosis. Considering the anti-apoptotic effect of exenatide in several studies, this effect was investigated in the H/R model. As shown in Fig. 4A and B, H/R-treated cells exhibited a significant increase in apoptosis $(\mathrm{P}<0.05)$. Compared with cells treated with $H / R$, the $H / R+$ exenatide group exhibited a significant decrease in the proportion of apoptotic cells $(\mathrm{P}<0.05)$. The expression of cleaved caspase-3 was also detected (Fig. 4C); it was observed that exenatide statistically significantly decreased the expression of cleaved caspase-3 in H/R-treated $\mathrm{H} 9 \mathrm{c} 2$ cells $(\mathrm{P}<0.05)$. These findings demonstrated that exenatide exerts anti-apoptotic effects on H/R-treated H9c2 cells.
Exenatide reduces the $H / R$-induced oxidative stress via the GLP-1 receptor/cAMP/PKA pathway in $H 9 c 2$ cells. Mitochondria are one of the major cellular sources of oxidative stress, and play a crucial role in oxidative injury during $\mathrm{H} / \mathrm{R}$; thus, the effects of exenatide on the generation of ROS and RNS induced by H/R were determined in H9c2 cells. As shown in Fig. 5, ROS and RNS were significantly increased in $\mathrm{H} 9 \mathrm{c} 2$ cells subjected to $\mathrm{H} / \mathrm{R}(\mathrm{P}<0.05)$, whereas exenatide reduced ROS and RNS generation in H/R-treated H9c2 cells $(\mathrm{P}<0.05)$. The results indicated that exenatide reduced $\mathrm{H} / \mathrm{R}$-induced oxidative stress in $\mathrm{H} 9 \mathrm{c} 2$ cells.

Next, the role of GLP-1 receptor/cAMP/PKA signaling pathway in the anti-oxidative effects of exenatide on $H / R$ injury was further evaluated. The GLP-1 receptor antagonist exendin-(9-39), the cAMP inhibitor Rp-cAMPS and the PKA inhibitor H-89 were employed. As shown in Fig. 5, the inhibitory effects of exenatide on H/R-induced ROS and RNS accumulation were significantly attenuated by treatment with exendin-(9-39), Rp-cAMPS and H-89 (P<0.05). Furthermore, in line with the results following exenatide pretreatment, pretreatment with the cAMP activator forskolin also reduced the production of ROS and RNS in $\mathrm{H} 9 \mathrm{c} 2$ cells subjected to $H / R$, suggesting that the reduction of the $H / R$-induced oxidative stress by exenatide is dependent on the GLP-1 receptor/cAMP/PKA pathway. Taken together, these results suggest that exenatide reduces the $\mathrm{H} / \mathrm{R}$-induced oxidative stress via activating the GLP-1 receptor/cAMP/PKA pathway in $\mathrm{H} 9 \mathrm{c} 2$ cells.

Exenatide reduces the H/R-induced $\left(\mathrm{Ca}^{2+}\right)_{m}$ overload and the opening of $M P T P$ via the GLP-1 receptor/cAMP/PKA pathway in $H 9 c 2$ cells. It is well-known that an increase in $\left(\mathrm{Ca}^{2+}\right)_{\mathrm{m}}$ impairs mitochondrial function; thus, the effects of exenatide on $\left(\mathrm{Ca}^{2+}\right)_{\mathrm{m}}$ changes induced by $\mathrm{H} / \mathrm{R}$ in $\mathrm{H} 9 \mathrm{c} 2$ cells were tested using flow cytometry. As shown in Fig. 6A, the $\left(\mathrm{Ca}^{2+}\right)_{\mathrm{m}}$ level in the H/R group was statistically significantly increased compared with that in the control group $(\mathrm{P}<0.05)$, while pretreatment with $0.2 \mu \mathrm{M}$ exenatide inhibited the increase of $\left(\mathrm{Ca}^{2+}\right)_{\mathrm{m}}$ induced by H/R $(\mathrm{P}<0.05)$. Similar to exenatide, forskolin $(0.1 \mu \mathrm{M})$ pretreatment also inhibited the increase of $\left(\mathrm{Ca}^{2+}\right)_{\mathrm{m}}$. However, incubation of cells with exendin-(9-39), Rp-cAMPS and H-89 abrogated the normalizing effect of exenatide on $\left(\mathrm{Ca}^{2+}\right)_{\mathrm{m}}(\mathrm{P}<0.05)$. These results indicated that exenatide attenuates the $\mathrm{H} / \mathrm{R}$-induced $\left(\mathrm{Ca}^{2+}\right)_{\mathrm{m}}$ overload via activating the GLP-1 receptor/cAMP/PKA pathway in $\mathrm{H} 9 \mathrm{c} 2$ cells. 


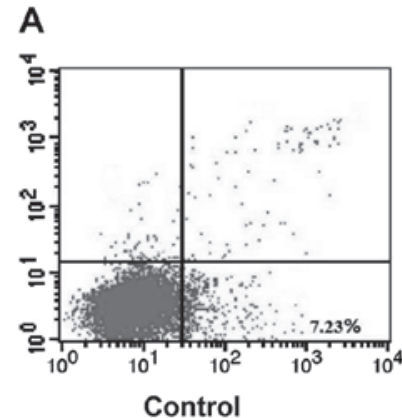

Control

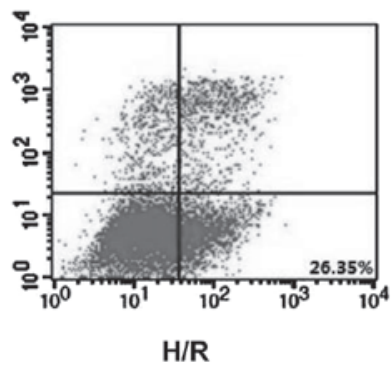

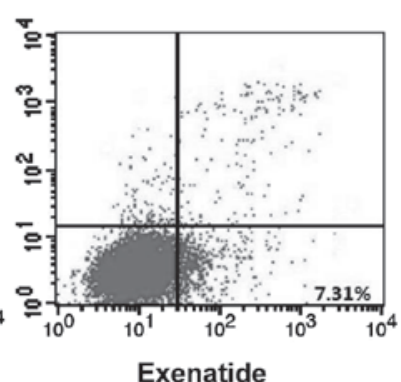

Exenatide

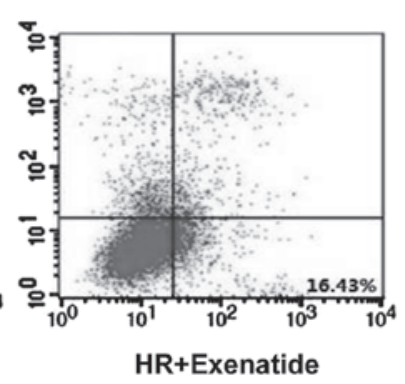

HR+Exenatide
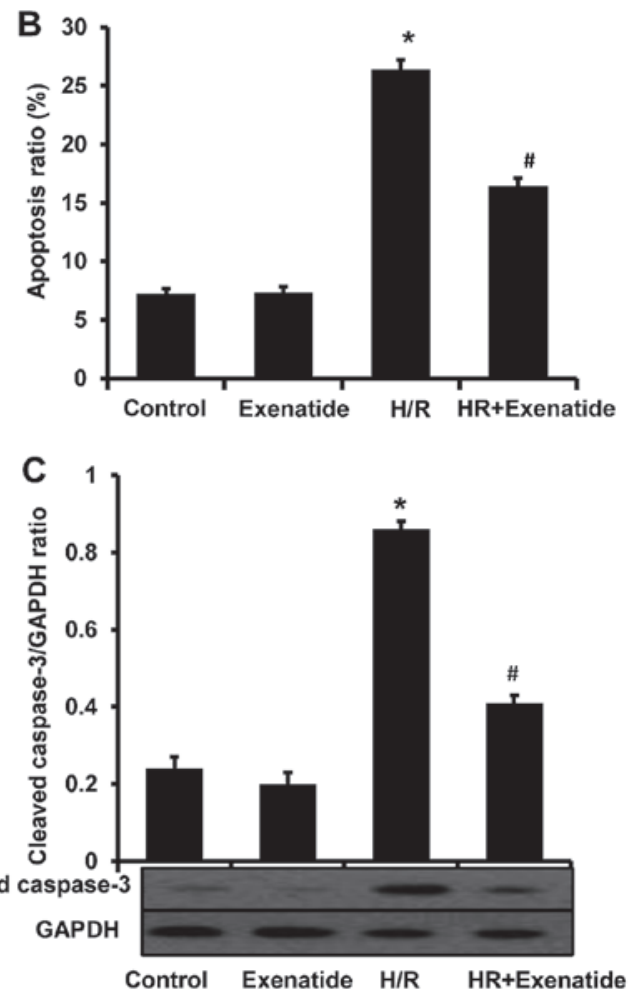

Figure 4. Effects of exenatide on hypoxia/reoxygenation (H/R)-induced apoptosis in H9c2 cells. H9c2 cells were pretreated with exenatide $(0.2 \mu \mathrm{M})$ for $30 \mathrm{~min}$ and underwent $12 \mathrm{~h}$ hypoxia followed by $4 \mathrm{~h}$ reoxygenation. After treatment, cell apoptosis ratio was measured by flow cytometry. (A) Representative images of flow cytometry. (B) Quantitative analyses of apoptosis ratio with the CellQuest ${ }^{\mathrm{TM}}$ software. (C) The cleaved caspase-3 expression was measured by western blotting, and data are expressed as ratio of cleaved caspase-3 to glyceraldehyde 3-phosphate dehydrogenase (GAPDH). Values are presented as mean \pm standard deviation; $n=6 .{ }^{*} \mathrm{P}<0.05$ vs. control group; ${ }^{*} \mathrm{P}<0.05$ vs. $\mathrm{H} / \mathrm{R}$ group.

A

$$
\text { A } 200
$$

Control

\section{Exenatide}

H/R

Ex9-39

Rp-cAMPS

H-89

Forskion
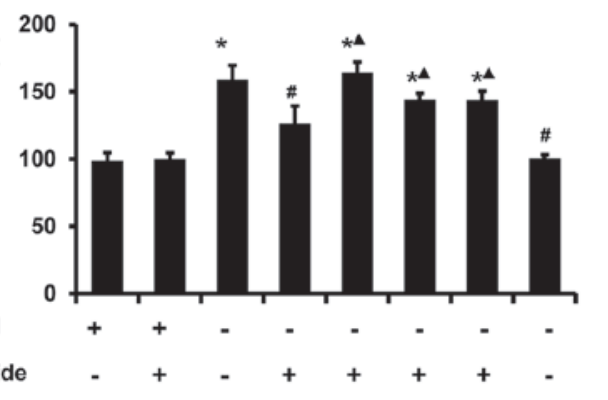

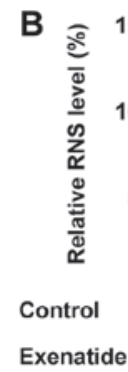

H/R

Ex9-39

Rp-cAMPS

H-89

Forskion

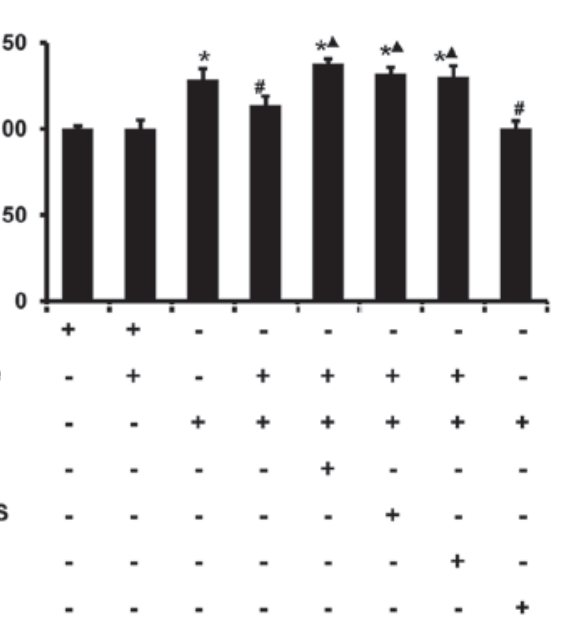

Figure 5. Effects of exenatide on reactive oxygen species (ROS) and reactive nitrogen species (RNS) generation in H9c2 cells. H9c2 cells were pretreated with exenatide $(0.2 \mu \mathrm{M})$ or forskolin $(1 \mu \mathrm{M})$ for $30 \mathrm{~min}$ prior to $12 \mathrm{~h}$ hypoxia followed by $4 \mathrm{~h}$ reoxygenation. The glucagon-like peptide-1 receptor antagonist exendin-(9-39) (Ex9-39) $(0.1 \mu \mathrm{M})$, the cAMP inhibitor Rp-cAMPS (200 $\mu \mathrm{M})$, and the protein kinase A inhibitor H-89 $(5 \mu \mathrm{M})$ were added to the cells for 10 min prior to treatment with exenatide. After treatment, ROS and RNS generation was measured by flow cytometry. (A) Quantitative analyses of 2',7'-dichlorofluorescin diacetate fluorescence intensity measured by flow cytometry. (B) Quantitative analyses of dihydroethidium fluorescence intensity measured by flow cytometry. Values are presented as mean \pm standard deviation, $n=3$. ${ }^{*} \mathrm{P}<0.05$ vs. control group; ${ }^{\#} \mathrm{P}<0.05$ vs. hypoxia/reoxygenation $(\mathrm{H} / \mathrm{R})$ group; ${ }^{\wedge} \mathrm{P}<0.05$ vs. $\mathrm{H} / \mathrm{R}+\mathrm{exenatide}$ group.

To further investigate the effects of exenatide on mitochondrial function, the status of mPTP was determined using calcein-AM probes by flow cytometry. Previous studies reported that the loading of calcein-AM enabled the localization of fluorescent calcein in mitochondria, and that the calcein-AM signal was reduced when the MPTP opened (26).
As shown in Fig. 6B, H/R treatment significantly decreased the calcein-AM fluorescence intensity compared with that of the control group $(\mathrm{P}<0.05)$, while pretreatment with exenatide or forskolin increased the calcein-AM signal intensity. When cells were pre-incubated with exendin-(9-39), Rp-cAMPS and $\mathrm{H}-89$, the effects of exenatide on calcein-AM intensity were 


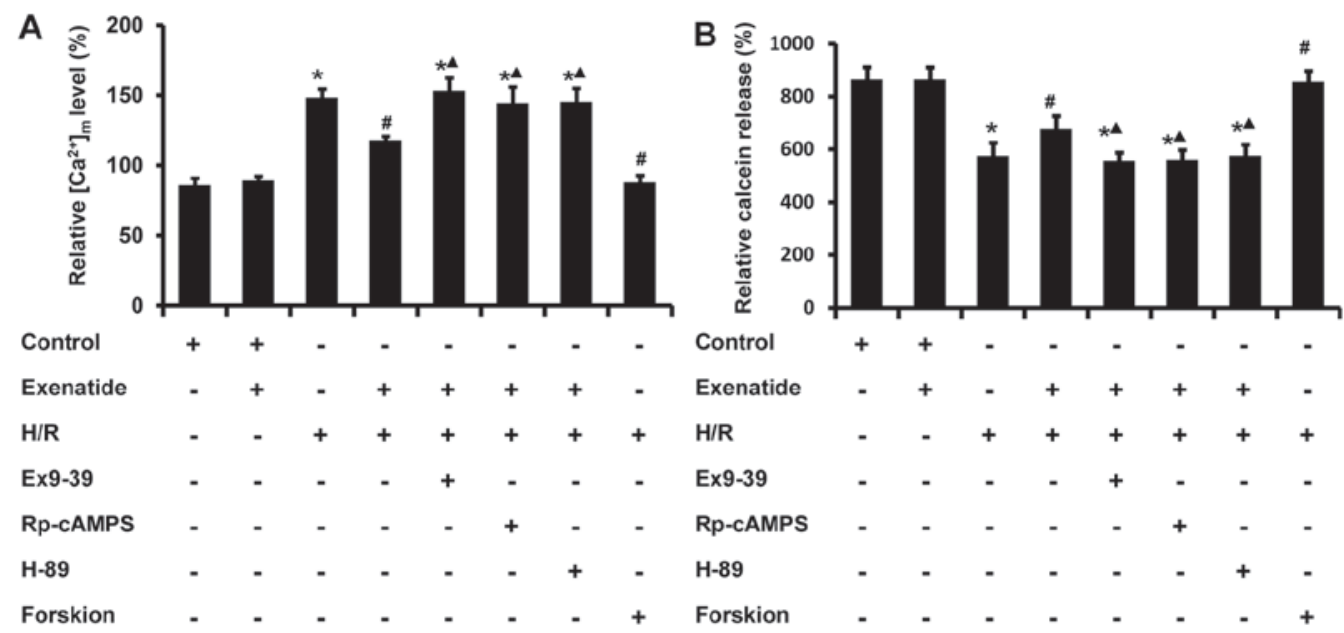

Figure 6. Effects of exenatide on mitochondrial calcium level $\left[\left(\mathrm{Ca}^{2+}\right)_{\mathrm{m}}\right]$ and the opening of mitochondrial permeability transition pore (mPTP) in H9c2 cells. $\mathrm{H} 9 \mathrm{c} 2$ cells were pretreated with exenatide $(0.2 \mu \mathrm{M})$ or forskolin $(1 \mu \mathrm{M})$ for 30 min prior to being subjected to $12 \mathrm{~h}$ hypoxia followed by $4 \mathrm{~h}$ reoxygenation. The glucagon-like peptide-1 receptor antagonist exendin-(9-39) (Ex9-39) (0.1 $\mu \mathrm{M})$, the cAMP inhibitor Rp-cAMPS (200 $\mu \mathrm{M})$, and the protein kinase A inhibitor $\mathrm{H}-89(5 \mu \mathrm{M})$ were added to the cells for $10 \mathrm{~min}$ prior to treatment with exenatide. After treatment, $\left(\mathrm{Ca}^{2+}\right)_{\mathrm{m}}$ and the opening of mPTP were measured by flow cytometry. (A) Quantitative analyses of Rhod-2 AM fluorescence intensity measured by flow cytometry. (B) Quantitative analyses of calcein-AM fluorescence intensity measured by flow cytometry. Values are presented as mean \pm standard deviation; $n=3$. ${ }^{*} \mathrm{P}<0.05$ vs. control group; ${ }^{*} \mathrm{P}<0.05$ vs. hypoxia/reoxygenation $(\mathrm{H} / \mathrm{R})$ group; ${ }^{\wedge} \mathrm{P}<0.05$ vs. $\mathrm{H} / \mathrm{R}+$ exenatide group.

A

$$
\text { 윰 }
$$

\section{Control}

(1)

\section{Exenatide}

H/R

Ex9-39

Rp-cAMPS

H-89

Forskion

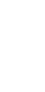
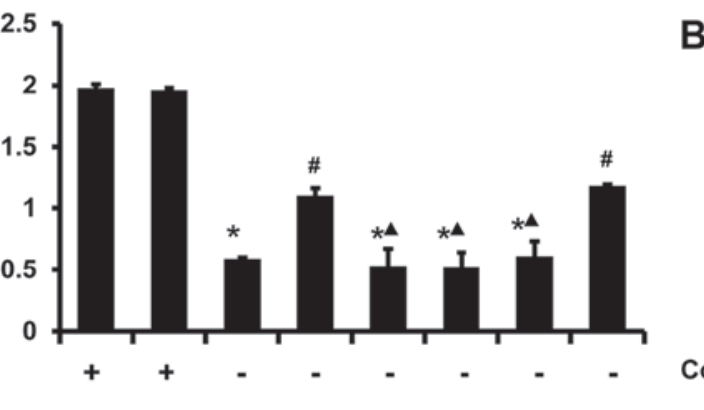

$+$

$$
-
$$

B

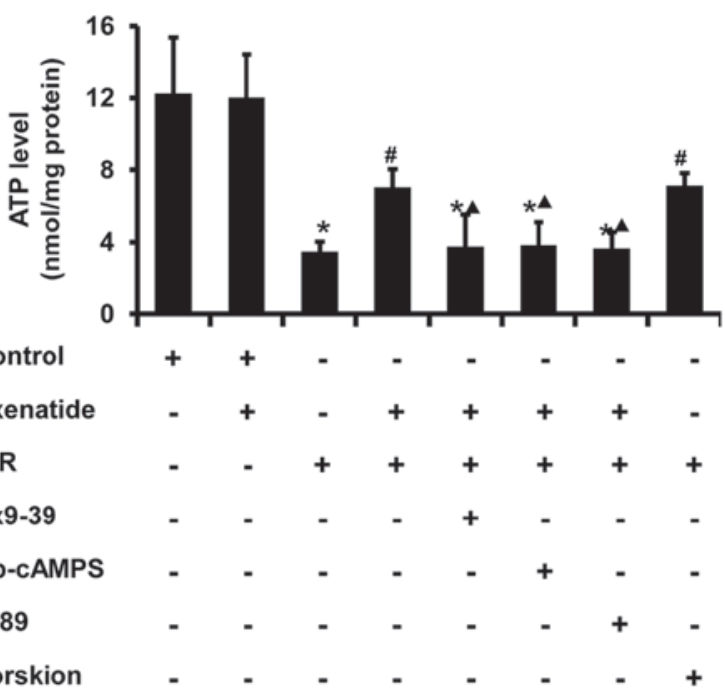

Figure 7. Effects of exenatide on mitochondrial membrane potential $(\Delta \Psi \mathrm{m})$ and ATP synthesis in H9c2 cells. H9c2 cells were pretreated with exenatide $(0.2 \mu \mathrm{M})$ or forskolin $(1 \mu \mathrm{M})$ for $30 \mathrm{~min}$ prior to being subjected to $12 \mathrm{~h}$ hypoxia followed by $4 \mathrm{~h}$ reoxygenation. The glucagon-like peptide-1 receptor antagonist exendin-(9-39) (Ex9-39) (0.1 $\mu \mathrm{M})$, the cAMP inhibitor Rp-cAMPS (200 $\mu \mathrm{M})$ and the protein kinase A inhibitor H-89 $(5 \mu \mathrm{M})$ were added to the cells for 10 min prior to treatment with exenatide. After treatment, the mitochondrial membrane potential was measured by flow cytometry. (A) Quantitative analyses of the JC-1 fluorescence ratio of red to green measured by flow cytometry. (B) Effects of exenatide on ATP synthesis in H9c2 cells. Cellular ATP content was measured using the ATP bioluminescent assay kit and expressed as nmol/mg protein. Values are presented as mean \pm standard deviation; $\mathrm{n}=3$. $\mathrm{P}<0.05 \mathrm{vs}$. control group; ${ }^{\text {}} \mathrm{P}<0.05$ vs. hypoxia/reoxygenation (H/R) group; ${ }^{\wedge} \mathrm{P}<0.05$ vs. $\mathrm{H} / \mathrm{R}+$ exenatide group.

inhibited $(\mathrm{P}<0.05)$. These results indicated that exenatide inhibits the H/R-induced opening of MPTP via activating the GLP-1 receptor/cAMP/PKA pathway in H9c2 cells.

Exenatide inhibits the $H / R$-induced depolarization of $\Delta \Psi m$ and the reduction of ATP synthesis in $H 9 c 2$ cells via the GLP-1 receptor/cAMP/PKA pathway. Since $\triangle \Psi \mathrm{m}$ is one of the indicators of mitochondrial function, the effect of exenatide on $\Delta \Psi \mathrm{m}$ was investigated. As shown in Fig. 7A, H/R treated cells exhibited a decrease in polarized mitochondria $(\mathrm{P}<0.05)$ and an increase in depolarized mitochondria $(\mathrm{P}<0.05)$ compared with the control group, whereas pretreatment with exenatide or forskolin reversed these changes $(\mathrm{P}<0.05)$; there was no significant difference between the $\mathrm{H} / \mathrm{R}+$ exenatide and $\mathrm{H} / \mathrm{R}+$ forskolin groups $(\mathrm{P}>0.05)$. When the cells were preincubated with exendin-(9-39), Rp-cAMPS and H-89, the effect of exenatide on $\Delta \Psi \mathrm{m}$ was inhibited $(\mathrm{P}<0.05)$. These results suggest that exenatide prevents $\Delta \Psi$ depolarization induced by $\mathrm{H} / \mathrm{R}$ via activating the GLP-1 receptor/cAMP/PKA pathway in $\mathrm{H} 9 \mathrm{c} 2$ cells.

Cellular ATP content is also a sensitive indicator of mitochondrial function. As shown in Fig. 7B, ATP concen- 

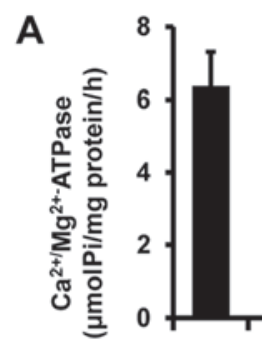

Control

Exenatide

H/R

Ex9-39

Rp-cAMPS

H-89

Forskion

Figure 8. Effects of exenatide on mitochondrial ATPase activity in H9c2 cells. H9c2 cells were pretreated with exenatide $(0.2 \mu \mathrm{M})$ or forskolin $(1 \mu \mathrm{M})$ for $30 \mathrm{~min}$ prior to being subjected to $12 \mathrm{~h}$ hypoxia followed by $4 \mathrm{~h}$ reoxygenation. The glucagon-like peptide-1 receptor antagonist exendin-(9-39) (Ex9-39) $(0.1 \mu \mathrm{M})$, the cAMP inhibitor Rp-cAMPS $(200 \mu \mathrm{M})$ and the protein kinase A inhibitor $\mathrm{H}-89(5 \mu \mathrm{M})$ were added to the cells for 10 min prior to treatment with exenatide. (A) Effects of exenatide on mitochondrial $\mathrm{Ca}^{2+} / \mathrm{Mg}^{2+}$-ATPase activity in $\mathrm{H} 9 \mathrm{c} 2$ cells. $\mathrm{Ca}^{2+} / \mathrm{Mg}^{2+}$-ATPase activity was measured using commercially available kits by colorimetry and was expressed as $\mu \mathrm{mol} \mathrm{Pi} / \mathrm{mg}$ protein/h. (B) Effects of exenatide on mitochondrial $\mathrm{Na}^{+} / \mathrm{K}^{+}-\mathrm{ATPase}$ activity in $\mathrm{H} 9 \mathrm{c} 2$ cells $\mathrm{Na}^{+} / \mathrm{K}^{+}$-ATPase activity was measured by colorimetry using commercially available kits and was expressed as $\mu \mathrm{mol} \mathrm{Pi} / \mathrm{mg}$ protein/h. Values are presented as mean \pm standard deviation; $\mathrm{n}=3$. ${ }^{*} \mathrm{P}<0.05$ vs. control group; ${ }^{*} \mathrm{P}<0.05$ vs. hypoxia/reoxygenation $(\mathrm{H} / \mathrm{R})$ group; ${ }^{\wedge} \mathrm{P}<0.05$ vs. $\mathrm{H} / \mathrm{R}+$ exenatide group.
A

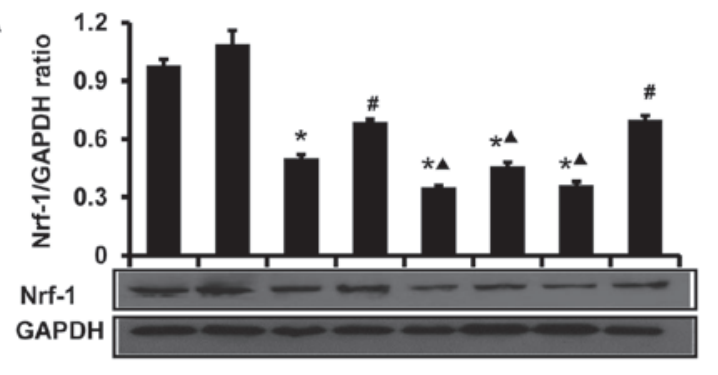

B

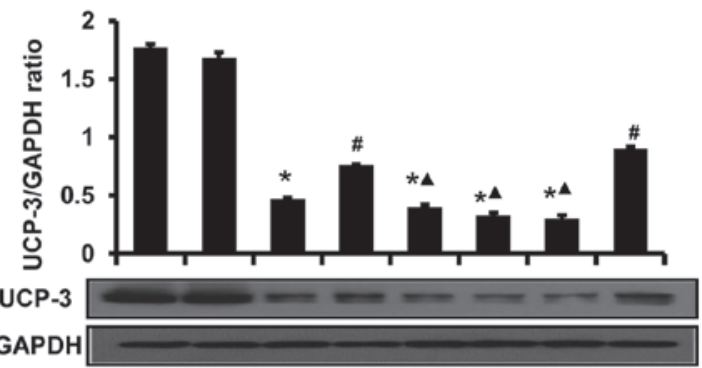

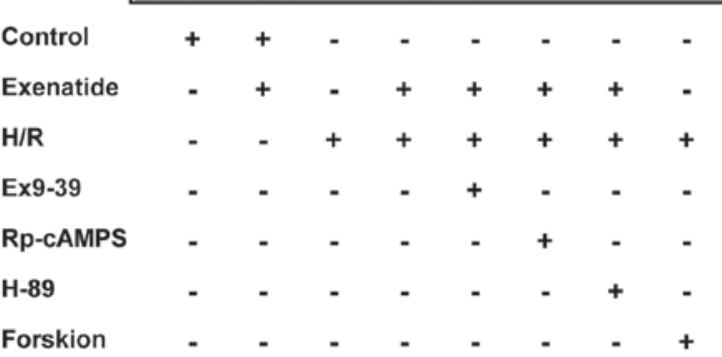

Figure 9. Effects of exenatide on nuclear respiratory factor-1 (Nrf-1) and uncoupling protein-3 (UCP-3) expression in H9c2 cells. H9c2 cells were pretreated with exenatide $(0.2 \mu \mathrm{M})$ or forskolin $(1 \mu \mathrm{M})$ for 30 min prior to being subjected to $12 \mathrm{~h}$ hypoxia followed by $4 \mathrm{~h}$ reoxygenation. The glucagon-like peptide-1 receptor antagonist exendin-(9-39) (Ex9-39) (100 nM), the cAMP inhibitor Rp-cAMPS, and the protein kinase A inhibitor H-89 were added to the cells for 10 min prior to treatment with exenatide. (A) Nrf-1 expression was measured by western blotting, and data were expressed as ratio of Nrf-1 to glyceraldehyde 3-phosphate dehydrogenase (GAPDH). (B) UCP-3 expression was measured by western blotting, and data were expressed as ratio of UCP-3 to GAPDH. Values are presented as mean \pm standard deviation; $\mathrm{n}=6 .{ }^{*} \mathrm{P}<0.05 \mathrm{vs}$. control group; ${ }^{\sharp} \mathrm{P}<0.05$ vs. hypoxia/reoxygenation $(\mathrm{H} / \mathrm{R})$ group; ${ }^{\wedge} \mathrm{P}<0.05 \mathrm{vs}$. $\mathrm{H} / \mathrm{R}+\mathrm{exenatide}$ group.

tration significantly decreased from $12.25 \mathrm{nmol} / \mathrm{mg}$ protein in the control group to $3.49 \mathrm{nmol} / \mathrm{mg}$ protein in the $\mathrm{H} / \mathrm{R}$ group $(\mathrm{P}<0.05)$. However, exenatide pretreatment resulted in an increase of cellular ATP level compared with that in the $\mathrm{H} / \mathrm{R}$ group $(\mathrm{P}<0.05)$, and these results were similar to those in the $\mathrm{H} / \mathrm{R}+$ forskolin group. By contrast, incubation of cells with exendin-(9-39), Rp-cAMPS and H-89 abrogated the effect of exenatide on cellular ATP content in H/R-treated cells $(\mathrm{P}<0.05)$. These results suggest that exenatide prevents the reduction of ATP synthesis induced by $\mathrm{H} / \mathrm{R}$ via activating the GLP-1 receptor/cAMP/PKA pathway in $\mathrm{H} 9 \mathrm{c} 2$ cells.

Exenatide inhibits the H/R-induced decrease of mitochondrial ATPaseactivity in H9c2 cellsviathe GLP-1 receptor/cAMP/PKA pathway. The activity of mitochondrial ATPase was further examined. As shown in Fig. 8, H/R-treated cells exhibited a significant decrease in the activity of $\mathrm{Na}^{+} / \mathrm{K}^{+}$ATPase $(\mathrm{P}<0.05)$ and $\mathrm{Ca}^{2+} / \mathrm{Mg}^{2+}$ ATPase $(\mathrm{P}<0.05)$, whereas exenatide pretreat- 
ment significantly increased the activity of $\mathrm{Na}^{+} / \mathrm{K}^{+}$ATPase $(\mathrm{P}<0.05)$ and $\mathrm{Ca}^{2+} / \mathrm{Mg}^{2+}$ ATPase $(\mathrm{P}<0.05)$ in $\mathrm{H} / \mathrm{R}$-treated cells; these results were similar to those in the $\mathrm{H} / \mathrm{R}+$ forskolin group. The effects of exenatide on ATPase in mitochondria were also inhibited by exendin-(9-39), Rp-cAMPS and H-89 $(\mathrm{P}<0.05)$. These findings provide evidence that exenatide maintains mitochondrial ATPase activity during $\mathrm{H} / \mathrm{R}$ via activating the GLP-1 receptor/cAMP/PKA pathway.

Exenatide inhibits the $H / R$-induced reduction of $U C P-3$ and Nrf-1 protein expression in $H 9 c 2$ cells via the GLP-1 receptor/cAMP/PKA pathway. The effects of exenatide on $\mathrm{UCP}-3$ and Nrf-1 protein expression in $\mathrm{H} 9 \mathrm{c} 2$ cells were analyzed by western blotting (Fig. 9). Compared with the control group, H/R treatment significantly decreased the levels of UCP-3 and Nrf-1 ( $<<0.05)$. Compared with the H/R group, exenatide significantly increased the UCP-3 and Nrf-1 levels $(\mathrm{P}<0.05)$, whereas UCP-3 and Nrf-1 levels did not differ significantly between the $\mathrm{H} / \mathrm{R}+$ exenatide and the $\mathrm{H} / \mathrm{R}+$ forskolin groups $(\mathrm{P}>0.05)$. However, the GLP-1 receptor antagonist exendin-(9-39), the cAMP inhibitor Rp-cAMPS and the PKA inhibitor $\mathrm{H}-89$ attenuated the effects of exenatide on UCP-3 and Nrf-1 $(\mathrm{P}<0.05)$. These results suggest that exenatide prevents the reduction of UCP-3 and Nrf-1 protein expression induced by $\mathrm{H} / \mathrm{R}$ via activating the GLP-1 receptor/cAMP/PKA pathway in $\mathrm{H} 9 \mathrm{c} 2$ cells.

\section{Discussion}

The main findings of this study revealed that exenatide exerted cardioprotective effects in an in vitro model of $\mathrm{H} / \mathrm{R}$, which resembles ischemia-reperfusion in vivo, by improving mitochondrial function, namely inhibiting the development of morphological abnormalities, opening of mPTP and depolarization of $\Delta \Psi \mathrm{m}$, decreasing mitochondrial oxidative stress and $\left(\mathrm{Ca}^{2+}\right)_{\mathrm{m}}$ overload, enhancing ATP synthesis and the activity of $\mathrm{Na}^{+} / \mathrm{K}^{+}$ATPase and $\mathrm{Ca}^{2+} / \mathrm{Mg}^{2+}$ ATPase. Importantly, these beneficial effects were abolished by treatment with exendin-(9-39), Rp-cAMPS and H-89, demonstrating that exenatide protects against ischemia-reperfusion injury via mitochondrial function improvement involving the GLP-1 receptor/cAMP/PKA signaling pathway.

GLP-1 must bind to the GLP-1 receptor, a specific $G$ protein-coupled receptor, in order to perform its cellular functions (13). The presence of the GLP-1 receptor has been demonstrated in a number of human organs and tissues, including the pancreas, heart, lung, kidney and brain $(13,14)$. However, there was no report on whether the GLP-1 receptor is expressed in the H9c2 cell line. In the present study, it was first proven that $\mathrm{H} 9 \mathrm{c} 2$ cells express the GLP-1 receptor using confocal laser scanning microscopy and western blot analysis.

Mitochondrial dysfunction plays a key role in myocardial injury during ischemia-reperfusion (3-5). In the present study, mitochondrial function was found to be severely impaired in $\mathrm{H} 9 \mathrm{c} 2$ cells subjected to $\mathrm{H} / \mathrm{R}$, as evidenced by reduced ATP synthesis, decreased activity of mitochondrial ATPases, opening of mPTP and depolarization of $\Delta \Psi \mathrm{m}$. Previous studies reported that changes in mitochondrial morphology may affect their biological processes and function (27). It was observed that $\mathrm{H} / \mathrm{R}$ treatment caused mitochondrial abnormalities, including swelling and disarrayed cristae, and these changes in shape are associated with the decrease in ATP synthesis and activity of mitochondrial ATPases. It is well-known that mitochondria, being a store of intracellular calcium, a source of ROS and a sensor of oxidative stress, play a key role in triggering necrotic and apoptotic cell death under a variety of pathological conditions, including ischemia-reperfusion injury (28-30). In the present study, exposure to H/R was found to reduce cell viability, increase the cell apoptotic rate, and increase the LDH and CK-MB levels in the cultured supernatant. Furthermore, $\mathrm{H} / \mathrm{R}$ injury also increased mitochondrial oxidative stress, as evidenced by increased ROS and RNS generation and $\left(\mathrm{Ca}^{2+}\right)_{\mathrm{m}}$ overload. Taken together, these findings indicate that $\mathrm{H} / \mathrm{R}$ treatment compromised the mitochondrial function, further contributing to cellular injury in the H/R model.

It is noteworthy that improved mitochondrial function with endogenous adjustment or artificial intervention accelerates recovery of cardiac and cellular functions subsequent to ischemia-reperfusion injury $(6,7,31,32)$. Therefore, treatments focused on preserving mitochondrial integrity and function hoping to minimize the impact of ischemia-reperfusion injury have become an area of intensive research. Various cardioprotective effects of GLP-1 and its analogues have been reported (15-19). Treatment with GLP-1 and its analogues may improve myocardial glucose uptake $(33,34)$ and metabolism $(35,36)$, as well as cardiac function $(34,37)$ in both animal models and clinical studies $(15,16)$. Several mechanisms underlying this cardioprotection have been proposed, such as activating the pro-survival kinase associated with reperfusion injury signaling kinase pathway (38), reducing oxidative stress and increasing antioxidants (37). Recently, Brown et al reported that the GLP-1 analogue exendin-4 exerted a persistent beneficial effect via altering the mitochondrial phenotype, which decreased the cardiac $\left(\mathrm{Ca}^{2+}\right)_{\mathrm{m}}$ uptake and reduced oxidative phosphorylation (20). To the best of our knowledge, the present study is the first to provide evidence that exenatide improves several characteristics of mitochondrial function (ATP synthesis, $\Delta \Psi \mathrm{m}, \mathrm{mPTP}$ and mitochondrial ATPase activity) following $\mathrm{H} / \mathrm{R}$ injury. We also demonstrated that exenatide treatment decreases the mitochondrial oxidative stress (decreased ROS and RNS generation and $\left(\mathrm{Ca}^{2+}\right)_{\mathrm{m}}$ overload) in the H/R model. Moreover, in line with previous results $(15,16,18)$, exenatide was found to reduce cell apoptosis and cell injury, resulting in increased viability of $\mathrm{H} 9 \mathrm{c} 2$ cells subjected to H/R. Based on the abovementioned results, exenatide was proven to exert cardioprotective effects in this cellular model of $\mathrm{H} / \mathrm{R}$ via improving mitochondrial function.

The cAMP/cAMP-dependent PKA signaling pathway (cAMP/PKA) is well-known to regulate cellular energy metabolism, critically affecting glucose transport and utilization (39), mitochondrial respiration and dynamics (40-42). It was recently revealed that activation of the cAMP/PKA pathway may be involved in GLP-1-mediated protective effects. Wang et al demonstrated that GLP-1 and its analogue exenatide protected against cardiac microvascular injury in diabetes via a cAMP/PKA/Rho-dependent mechanism (43). Xiao et al observed that GLP-1 enhanced cardiac L-type $\mathrm{Ca}^{2+}$ currents through the cAMP/PKA pathway (44). Bose et al reported that GLP-1 treatment may attenuate ischemia-reper- 
fusion injury, at least in part via activation of PKA (45-47). Based on the abovementioned findings, we hypothesized that the protective effects of exenatide on mitochondrial function in $\mathrm{H} / \mathrm{R}$ injury may be associated with activation of the cAMP/PKA pathway via binding to the GLP-1 receptor. In the present study, it was observed that the exenatide-induced improvement of mitochondrial function (ATP synthesis, $\triangle \Psi \mathrm{m}, \mathrm{mPTP}$ and mitochondrial ATPase activity) was abolished by the GLP-1 receptor inhibitor exendin-(9-39), the cAMP inhibitor Rp-cAMPS, and the PKA inhibitor H-89. To further examine the mechanism underlying the effect of exenatide on mitochondrial function, forskolin, a potent activator of cAMP, was employed to activate the cAMP/PKA pathway. We observed that both exenatide and forskolin exerted a similar protective effect on mitochondrial function in $\mathrm{H} / \mathrm{R}$ injury. These results strongly suggest that exenatide may improve mitochondrial function in $\mathrm{H} / \mathrm{R}$ injury, at least in part though activation of the GLP-1 receptor/cAMP/PKA signaling pathway.

Mitochondrial UCPs and Nrf-1 are both known downstream effectors of the cAMP/PKA pathway. UCPs belong to the superfamily of anion carrier proteins and are located in the inner mitochondrial membrane (48). Previous studies demonstrated that overexpression of UCPs in cardiomyocytes may prevent cell death by preserving mitochondrial function and structure $(49,50)$. The present study demonstrated that exenatide treatment enhanced the expression of UCP-3, which was associated with improvement of mitochondrial function in $\mathrm{H} 9 \mathrm{c} 2$ cardiomyocytes subjected to $\mathrm{H} / \mathrm{R}$, while these effects were abolished by the GLP-1 receptor inhibitor exendin-(9-39), the cAMP inhibitor Rp-cAMPS and the PKA inhibitor H-89. Nrf-1 is a key nuclear transcription factor that regulates the expression of nuclear mitochondrial genes encoding proteins of the mitochondrial respiratory chain and oxidative phosphorylation $(51,52)$. Therefore, Nrf-1 plays an important role in regulating mitochondrial biogenesis and respiratory function (53). The present study demonstrated that exenatide upregulated the expression of Nrf-1 in H/R-treated H9c2 cardiomyocytes. Furthermore, the results revealed that upregulation of Nrf-1 was associated with improvement of mitochondrial function. These beneficial effects were also abolished by exendin-(9-39), Rp-cAMPS and H-89. Although the present study did not evaluate any other proteins responsible for mitochondrial function, the cAMP/PKA pathway was correlated with its downstream factors (UCP-3 and Nrf-1) using the inhibitors of cAMP/PKA. Taken together, our data further indicated that exenatide prevented H/R-induced mitochondrial dysfunction, possibly through upregulation of UCP-3 and Nrf-1 via activation of the GLP-1 receptor/cAMP/PKA signaling pathway.

In conclusion, the data of the present study demonstrated that the GLP-1 analogue exenatide exerted cardioprotective effects in an in vitro model of $\mathrm{H} / \mathrm{R}$, which resembles ischemia-reperfusion in vivo, and that this cardioprotection may be attributed to the improvement of mitochondrial function. These effects are most likely associated with activation of the GLP-1 receptor and the cAMP/PKA signaling pathway. These findings highlight a novel mechanism underlying the cardioprotective effects of GLP-1 analogues and the improvement of myocardial ischemia-reperfusion injury.

\section{Acknowledgements}

The present study was supported by the National Natural Science Fund (grant no. 85170212), the Natural Science Foundation Project of CQ CSTC (grant no. cstc2011jjA10008) and the National key Clinical Specialties Construction Program of China (grant no. 2011-170). The authors greatly appreciate the excellent technical support of Mr. Jianyong Wu and Mr. Dezhang Zhao (Institute of Life Sciences, Chongqing Medical University) for the flow cytometry analysis.

\section{References}

1. Braunwald E and Kloner RA: Myocardial reperfusion: A doubleedged sword? J Clin Invest 76: 1713-1719, 1985.

2. Acar E, Ural D, Bildirici U, Sahin T and Y1lmaz I: Diabetic cardiomyopathy. Anadolu Kardiyol Derg 11: 732-737, 2011.

3. Ong SB and Gustafsson AB: New roles for mitochondria in cell death in the reperfused myocardium. Cardiovasc Res 94: 190-196, 2012.

4. Honda HM, Korge $\mathrm{P}$ and Weiss JN: Mitochondria and ischemia/reperfusion injury. Ann NY Acad Sci 1047: 248-258, 2005.

5. Lesnefsky EJ and Hoppel CL: Ischemia-reperfusion injury in the aged heart: Role of mitochondria. Arch Biochem Biophys 420: 287-297, 2003.

6. Sun L, Zhao M, Yu XJ, Wang H, He X, Liu JK and Zang WJ: Cardioprotection by acetylcholine: A novel mechanism via mitochondrial biogenesis and function involving the PGC-1 $\alpha$ pathway. J Cell Physiol 228: 1238-1248, 2013.

7. Yue R, Hu H, Yiu KH, Luo T, Zhou Z, Xu L, Zhang S, Li K and Yu Z: Lycopene protects against hypoxia/reoxygenation-induced apoptosis by preventing mitochondrial dysfunction in primary neonatal mouse cardiomyocytes. PLoS One 7: e50778, 2012.

8. Rehman H, Shi Y and Zhong Z: Ischemia/reperfusion inhibits mitochondrial biogenesis after partial hepatectomy in mice: 1738 . Transplantation 90: 839, 2010.

9. Ren J, Pulakat L, Whaley-Connell A and Sowers JR: Mitochondrial biogenesis in the metabolic syndrome and cardiovascular disease. J Mol Med (Berl) 88: 993-1001, 2010.

10. Rimbaud S, Garnier A and Ventura-Clapier R: Mitochondrial biogenesis in cardiac pathophysiology. Pharmacol Rep 61: 131-138, 2009.

11. Garber AJ: Novel GLP-1 receptor agonists for diabetes. Expert Opin Investig Drugs 21: 45-57, 2012.

12. Mundil D, Cameron-Vendrig A and Husain M: GLP-1 receptor agonists: A clinical perspective on cardiovascular effects. Diab Vasc Dis Res 9: 95-108, 2012.

13. Baggio LL and Drucker DJ: Biology of incretins: GLP-1 and GIP. Gastroenterology 132: 2131-2157, 2007.

14. Wei Y and Mojsov S: Tissue-specific expression of the human receptor for glucagon-like peptide-I: Brain, heart and pancreatic forms have the same deduced amino acid sequences. FEBS Lett 358: 219-224, 1995.

15. Chinda K, Chattipakorn S and Chattipakorn N: Cardioprotective effects of incretin during ischaemia-reperfusion. Diab Vasc Dis Res 9: 256-269, 2012.

16. Ravassa S, Zudaire A and Díez J: GLP-1 and cardioprotection: From bench to bedside. Cardiovasc Res 94: 316-323, 2012.

17. Bao W, Holt LJ, Prince RD, Jones GX, Aravindhan K, Szapacs M, Barbour AM, Jolivette LJ, Lepore JJ, Willette RN, et al: Novel fusion of GLP-1 with a domain antibody to serum albumin prolongs protection against myocardial ischemia/reperfusion injury in the rat. Cardiovasc Diabetol 12: 148, 2013.

18. Zhao TC: Glucagon-like peptide-1 (GLP-1) and protective effects in cardiovascular disease: A new therapeutic approach for myocardial protection. Cardiovasc Diabetol 12: 90, 2013.

19. Liu Q, Anderson C, Broyde A, Polizzi C, Fernandez R, Baron A and Parkes DG: Glucagon-like peptide-1 and the exenatide analogue AC3174 improve cardiac function, cardiac remodeling, and survival in rats with chronic heart failure. Cardiovasc Diabetol 9: 76, 2010.

20. Brown SB,Libonati JR, Selak MA, Shannon RP and Simmons RA: Neonatal exendin-4 leads to protection from reperfusion injury and reduced rates of oxidative phosphorylation in the adult rat heart. Cardiovasc Drugs Ther 24: 197-205, 2010. 
21. Tomas E, Stanojevic V and Habener JF: GLP-1-derived nonapeptide GLP-1(28-36)amide targets to mitochondria and suppresses glucose production and oxidative stress in isolated mouse hepatocytes. Regul Pept 167: 177-184, 2011.

22. Park M, Youn B, Zheng XL, Wu D, Xu A and Sweeney G: Globular adiponectin, acting via AdipoR1/APPL1, protects H9c2 cells from hypoxia/reoxygenation-induced apoptosis. PLoS One 6: e19143,2011.

23. Wang L, Wang ZH, Shen CY, You ML, Xiao JF and Chen GQ Differentiation of human bone marrow mesenchymal stem cells grown in terpolyesters of 3-hydroxyalkanoates scaffolds into nerve cells. Biomaterials 31: 1691-1698, 2010.

24. Kumar S, Kain V, Sitasawad SL: High glucose-induced Ca2p overload and oxidative stress contribute to apoptosis of cardiac cells through mitochondrial dependent and independent pathways. Biochim Biophys Acta 1820: 907-920, 2012.

25. Odagiri K, Katoh H, Kawashima H, Tanaka T, Ohtani H, Saotome M, Urushida T, Satoh H and Hayashi H: Local control of mitochondrial membrane potential, permeability transition pore and reactive oxygen species by calcium and calmodulin in rat ventricular myocytes. J Mol Cell Cardiol 46: 989-997, 2009.

26. Tominaga H, Katoh H, Odagiri K, Takeuchi Y, Kawashima H, Saotome M, Urushida T, Satoh H and Hayashi H: Different effects of palmitoyl-L-carnitine and palmitoyl-CoA on mitochondrial function in rat ventricular myocytes. Am J Physiol Heart Circ Physiol 295: H105-H112, 2008.

27. Ong SB, Subrayan S, Lim SY, Yellon DM, Davidson SM and Hausenloy DJ: Inhibiting mitochondrial fission protects the heart against ischemia/reperfusion injury. Circulation 121: 2012-2022, 2010.

28. Halestrap AP, Clarke SJ, Khaliulin I: The role of mitochondria in protection of the heart by preconditioning. Biochim Biophys Acta 1767: 1007-1031, 2007.

29. Li Q, Zhou LY, Gao GF, Jiao JQ and Li PF: Mitochondrial network in the heart. Protein Cell 3: 410-418, 2012.

30. Crow MT, Mani K, Nam YJ and Kitsis RN: The mitochondrial death pathway and cardiac myocyte apoptosis. Circ Res 95 957-970, 2004

31. Garlid KD, Costa AD, Quinlan CL, Pierre SV and Dos Santos P Cardioprotective signaling to mitochondria. J Mol Cell Cardiol 46: 858-866, 2009.

32. Perrelli MG, Pagliaro P and Penna C: Ischemia/reperfusion injury and cardioprotective mechanisms: Role of mitochondria and reactive oxygen species. World J Cardiol 3: 186-200, 2011.

33. Zhao T, Parikh P, Bhashyam S, Bolukoglu H, Poornima I, Shen YT and Shannon RP: Direct effects of glucagon-like peptide-1 on myocardial contractility and glucose uptake in normal and postischemic isolated rat hearts. J Pharmacol Exp Ther 317: 1106-1113, 2006.

34. Nikolaidis LA, Elahi D, Hentosz T, Doverspike A, Huerbin R, Zourelias L, Stolarski C, Shen YT and Shannon RP: Recombinant glucagon-like peptide- 1 increases myocardial glucose uptake and improves left ventricular performance in conscious dogs with pacing-induced dilated cardiomyopathy. Circulation 110 955-961, 2004

35. Luque MA, González N, Márquez L, Acitores A, Redondo A Morales M, Valverde I and Villanueva-Peñacarrillo ML: Glucagon-like peptide-1 (GLP-1) and glucose metabolism in human myocytes. J Endocrinol 173: 465-473, 2002.

36. Bao W, Aravindhan K, Alsaid H, Chendrimada T, Szapacs M Citerone DR, Harpel MR, Willette RN, Lepore JJ and Jucker BM: Albiglutide, a long lasting glucagon-like peptide-1 analog, protects the rat heart against ischemia/reperfusion injury: Evidence for improving cardiac metabolic efficiency. PLoS One 6: e23570, 2011
37. Timmers L, Henriques JP, de Kleijn DP, Devries JH, Kemperman H, Steendijk P, Verlaan CW, Kerver M, Piek JJ, Doevendans PA, et al: Exenatide reduces infarct size and improves cardiac function in a porcine model of ischemia and reperfusion injury. J Am Coll Cardiol 53: 501-510, 2009.

38. Ban K, Noyan-Ashraf MH, Hoefer J, Bolz SS, Drucker DJ and Husain M: Cardioprotective and vasodilatory actions of glucagon-like peptide 1 receptor are mediated through both glucagon-like peptide 1 receptor-dependent and -independent pathways. Circulation 117: 2340-2350, 2008.

39. Depre C, Ponchaut S, Deprez J, Maisin L and Hue L: Cyclic AMP suppresses the inhibition of glycolysis by alternative oxidizable substrates in the heart. J Clin Invest 101: 390-397, 1998.

40. De Rasmo D, Gattoni G, Papa F, Santeramo A, Pacelli C, Cocco T, Micelli L, Sardaro N, Larizza M, Scivetti M, et al: The $\beta$-adrenoceptor agonist isoproterenol promotes the activity of respiratory chain complex I and lowers cellular reactive oxygen species in fibroblasts and heart myoblasts. Eur J Pharmacol 652: $15-22,2011$

41. Acin-Perez R, Salazar E, Kamenetsky M, Buck J, Levin LR and Manfredi G: Cyclic AMP produced inside mitochondria regulates oxidative phosphorylation. Cell Metab 9: 265-276, 2009.

42. Valsecchi F, Ramos-Espiritu LS, Buck J, Levin LR and Manfredi G: cAMP and mitochondria. Physiology (Bethesda) 28: 199-209, 2013

43. Wang D, Luo P, Wang Y, Li W, Wang C, Sun D, Zhang R, Su T, Ma X, Zeng C, et al: Glucagon-like peptide-1 protects against cardiac microvascular injury in diabetes via a cAMP/PKA/Rho-dependent mechanism. Diabetes 62: 1697-1708, 2013.

44. Xiao YF, Nikolskaya A, Jaye DA and Sigg DC: Glucagon-like peptide- 1 enhances cardiac L-type $\mathrm{Ca}^{2+}$ currents via activation of the cAMP-dependent protein kinase A pathway. Cardiovase Diabetol 10: 6, 2011

45. Bose AK, Mocanu MM, Carr RD and Yellon DM: Glucagon like peptide-1 is protective against myocardial ischemia/reperfusion injury when given either as a preconditioning mimetic or at reperfusion in an isolated rat heart model. Cardiovasc Drugs Ther 19: 9-11, 2005.

46. Bose AK, Mocanu MM, Carr RD, Brand CL and Yellon DM: Glucagon-like peptide 1 can directly protect the heart against ischemia/reperfusion injury. Diabetes 54: 146-151, 2005.

47. Bose AK, Mocanu MM, Carr RD and Yellon DM: Myocardial ischaemia-reperfusion injury is attenuated by intact glucagon like peptide-1 (GLP-1) in the in vitro rat heart and may involve the p70s6K pathway. Cardiovasc Drugs Ther 21: 253-256, 2007.

48. Krauss S, Zhang CY and Lowell BB: The mitochondrial uncoupling-protein homologues. Nat Rev Mol Cell Biol 6: 248-261, 2005

49. Teshima Y, Akao M, Jones SP and Marbán E: Uncoupling protein-2 overexpression inhibits mitochondrial death pathway in cardiomyocytes. Circ Res 93: 192-200, 2003.

50. Bienengraeber M, Ozcan C and Terzic A: Stable transfection of UCP1 confers resistance to hypoxia/reoxygenation in a heart-derived cell line. J Mol Cell Cardiol 35: 861-865, 2003.

51. Scarpulla RC: Nuclear control of respiratory gene expression in mammalian cells. J Cell Biochem 97: 673-683, 2006.

52. Scarpulla RC: Nuclear control of respiratory chain expression by nuclear respiratory factors and PGC-1-related coactivator. Ann NY Acad Sci 1147: 321-334, 2008

53. Javadov S, Purdham DM, Zeidan A and Karmazyn M: NHE-1 inhibition improves cardiac mitochondrial function through regulation of mitochondrial biogenesis during postinfarction remodeling. Am J Physiol Heart Circ Physiol 291: H1722-H1730, 2006. 